\title{
Cristina GHERASIM*
}

\section{POLITICA ADMINISTRAŢIEI IMPERIALE RUSE PRIVIND ACORDAREA TITLURILOR NOBILIARE ÎN BASARABIA ÎN PRIMA JUMĂTATE A SECOLULUI AL XIX-LEA}

\section{The Politics of the Russian Administration Concerning Nobility Titles in Bessarabia in the First Half of the XIX ${ }^{\text {th }}$ Century}

\begin{abstract}
By looking at archive documents and published monographic studies, the article concerns the Russian imperial administration policy for granting noble titles in Bessarabia. The Tsar, joining the territory between the Pruth and Dniester rivers, wanted to attract Bessarabian nobles by all means. The annexation called not only for time, but for big efforts from Bessarabian noble families as well, as they had to confirm not just their noble status, but also the right on farmland possessions over the lands they had owned. Therefore, for a long period of time Bessarabian nobles had to present to the Russian administration documents confirmed by Moldovan rulers, civil or church authorities, that would eventually confirm their noble origin. In order to create a social base to support and promote imperial policy, the imperial administration directed an intense colonization of the territory and an infiltration among native nobility of Russian nobles or just simple clerks of Russian origin coming from different parts such as Poland, Austria, etc. The Tsarist administration`s policy of nobility confirmation tended to control upper society, as to create a social base that would support and promote the imperial policy in the newly annexed territory.
\end{abstract}

Keywords: Bessarabia, nobility, tsarism, nobility title, discipline

Dreptul de a se identifica drept nobili şi de a putea beneficia de privilegiile şi drepturile specifice acestei categorii sociale a generat tendinţa permanentă a unor reprezentanţi ai populaţiei de a opta pentru a fi incluşi în această categorie privilegiată,

\footnotetext{
${ }^{*}$ Universitatea de Stat din Moldova, Institutul de Istorie al Academiei de Științe a Moldovei; gherasimcristina14@gmail.com.
} 
fapt constatat şi în spaţiul dintre Prut şi Nistru. În Basarabia acest proces a avut o dublă conotaţie: pe de o parte, acordarea titlurilor nobiliare a fost o componentă a politicii imperiale promovate de administraţia ţaristă în teritoriile nou-anexate, iar, pe de altă parte, boierii, boiernaşii, funcţionarii etc. au tins să beneficieze cu orice preţ de titlul de dvorean/nobil. Căci atât boierii, cât şi clerul, susţine Nicolae Bălcescu, căutară mereu a se constitui în caste, dobândindu-şi privilegii şi concentrând toate drepturile în mâinile lor ${ }^{1}$.

De fapt, analiza politicii promovate de administraţia imperială privind acordarea titlurilor nobiliare în Basarabia după anexare este imposibilă fără a ne clarifica asupra faptului ce reprezenta prin sine boierimea din Principatul Moldova şi dvorenimea din Imperiului Rus la începutul secolului al XIX-lea. În Țările Române, la fel ca şi în alte state ale lumii, a existat o categorie socială privilegiată, numită boierime. Ea a fost una dintre categoriile sociale de bază ale societăţii româneşti. Fără a intra în detalii, trebuie să constatăm că sunt diferite păreri ale istoricilor despre provenienţa, criteriile şi rolul nobleţei în viaţa politică, economică şi socială din teritoriu. Cărturarul Dimitrie Cantemir susţine că numele de boieri, provine de la slavonul „boliare”, cuvânt cu care slavii vechi obişnuiau să-i numească pe mai marii lor $^{2}$. Radu Rosetti susţine că boierii reprezentau înalţii demnitari ai statului, care alcătuiau Sfatul Domnesc. Această denumire cuprinde şi pe boierii care ocupau funcţii ${ }^{3}$. Autorul face o deosebire între boierimea din timpul descălecării şi cea de mai târziu. Prima era formată din cneji şi urmaşii lor, iar a doua e rezultatul transformării acestora în clasă stăpânitoare de pământ, fenomen ce s-a desfăşurat în secolele XVXVII ${ }^{4}$. Astfel, urmaşii cnejilor făceau totodată slujba domnului, iar pentru a răsplăti credinţa şi serviciile faţă de persoana sa, domnul dăruia proprietăţi funciare. A.D. Xenopol susţine că în Ţările Române a existat o nobilime ereditară, care se trăgea încă din timpul încetării stăpânirii avare şi se explică prin influenţa slavonă. Cuvântul „boljar" derivă de la slavonul „boi", luptă, război, deoarece boierii aveau datoria de a merge la război ${ }^{5}$. Istoricul român C.C. Giurescu identifică trei etape în evoluţia boierimii în Ţările Române, în dependenţă de criteriul nobleţei. La început, susţine autorul, criteriul fundamental al nobleței a fost stăpânirea pământului ${ }^{6}$, ulterior, în secolul al XVIII-lea (pe timpul lui Dimitrie Cantemir), criteriul nobleţei îl formează deopotrivă slujba ca şi moşia ${ }^{7}$. Sub Constantin Mavrocordat evoluţia în acest sens este

\footnotetext{
${ }^{1}$ Mitrică, Temelie s.a: 4

${ }^{2}$ Cantemir 1975: 116.

${ }^{3}$ Rosetti 1907: 31.

${ }^{4}$ Rosetti 1907: 232.

${ }^{5}$ Xenopol 1988: 171.

${ }^{6}$ Giurescu 1946: 715.

${ }^{7}$ Giurescu 1946: 718.
} 
încheiată: boierii sunt numai aceia care deţin sau au deţinut slujbe ${ }^{8}$. Referindu-se la boierimea din Moldova, Gh. Bezviconi, cel care s-a preocupat în special de boierimea dintre Prut şi Nistru, menţiona că ereditatea privilegiilor boiereşti rămâne la noi formală, fictivă, căci nu doar boierimea în sine, dar şi titlul urmaşilor de Domni nu este determinat printr-o succesiune. Deşi neereditară formal, totuşi boierimea pământeană are unele îndatoriri vasale faţă de Domn, mai ales aceea de a apăra ţara, venind cu oameni, arme şi cai în oastea Suveranului ${ }^{9}$. Referindu-se la această problemă, Neagu Djuvara susţine că termenul boier era ambiguu: boierimea desemna calitatea de nobil, în general, iar boierie - slujba sau dregătoria deţinută în aparatul de stat. Potrivit tradiţiei bizantine, puteai fi boier dacă erai fiu de boier sau când căpătai de la domnitor dregătoriile, de pildă, de logofăt sau de spătar. Începând cu mijlocul secolului al XIX-lea, termenul boier, după Neagu Djuvara, va desemna mare moşier, oricare ar fi fost obârşia lui socială ${ }^{10}$.

Procesul de înnobilare, care era strâns legat de deţinerea funcţiilor în stat, este descris în Principatul Moldova de Dimitrie Cantemir. Marele cărturar moldovean menţiona că „odinioară era la moldoveni obiceiul (...) să nu se dea dregătorii oamenilor tineri, măcar de se trăgeau din neamurile cele mai de frunte, până nu-şi dovedeau credinţa în alte slujbe mai mici" ${ }^{11}$. De fapt, procesul de obţinere a rangurilor boiereşti în Ţara Moldovei începea cu încadrarea fiilor boierilor, după ce treceau de vârsta copilăriei, să slujească pe la boierii din starea întâi, unde timp de trei ani învăţau obiceiurile Curţii şi purtarea aleasă, apoi erau promovaţi cămăraşi ai divanului mare, apoi ai divanului cel mic şi de aici în spătărie. Şi abia „după ce-şi petrecea în chipul acesta tinereţea, îl ridica mai întâi în starea a treia a boierilor şi la urmă în starea cea dintâi" ${ }^{\prime 2}$. Din cele expuse putem constata că, spre deosebire de situaţia în Europa Occidentală, unde titlul nobiliar se transmitea prin ereditate, în Moldova pentru început acest titlu nu era ereditar. Or, drumul pe care trebuia să-l urmeze o persoană pentru a beneficia de privilegiile specifice categoriei sociale a boierimii era destul de lung; deci la finele lui urmau să ajungă oamenii cei mai destoinici în aceste ranguri. Însă Dimitrie Cantemir susţine că situaţia s-a schimbat la începutul secolului al XVIIIlea: „În zilele noastre, când semeţia creşte odată cu sărăcia, un boier cugetă că şi-ar ruşina starea, dacă ar trebui să slujească la alt boier" ${ }^{\prime 13}$. Astfel, se trece la faptul că

\footnotetext{
${ }^{8}$ Giurescu 1946: 718.

${ }^{9}$ Bezviconi 1943: 12.

${ }^{10}$ Djuvara 1995: 121.

${ }^{11}$ Cantemir 2001: 164.

${ }^{12}$ Cantemir 2001: 164.

${ }^{13}$ Cantemir 2001: 165.
} 
fiecare boier caută prin intermediul rudelor sale ,să fie primit în rândul slujitorilor de taină" ${ }^{14}$ şi să capete o slujbă în stat şi, respectiv, un statut social privilegiat.

Ulterior, prin reforma lui Constantin Mavrocordat boierimii din Principate iau fost acordate noi drepturi şi privilegii. Astfel, până la adoptarea acestei legi, conform tradiţiei existente „măcară că aicea era obiceiu”, scutiţi de impozite erau doar boierii care deţineau dregătorii - de la vel logofăt până la vel stolnic, însă în caz că erau „maziliţi, atunci ei trebuiau să achite dajdia”. Însă prin hrisovul adoptat de Constantin Mavrocordat în anul 1734 s-a hotărât ca acest drept să fie acordat pe viaţă şi transmis prin ereditate. Legea confirma că „de acumu înainte boiarii, care sunt şi vor fi supt această stăpânire, începând de la vel logăfăt pâna la treti logofăt, atâta dumisale, cât şi fii dumilorsale, nu mai când vor fi întru dregătorii, ce şi lipsiţi fiind de dajde mazilească, ce da pre an, să fie slobozi şi iertaţi în veaţi, nime să nu-i bântuiască, sau să-i supere, cerşindu-le dajde" ${ }^{\prime 15}$. Motivul invocat de domn este slujba credincioasă pe care o realizează boierii. Izvorul confirma: „Făcut-am domnia mea acestu căzut năstav, socotind că întăivinitul dregătorilor sale iaste puțin, al doile, şi mai vârtos, întru lauda şi cinste domnii şi a toată, de Dumnezău păzită ţara aceasta""16.

Astfel, boierimea din Principatul Moldova reprezenta o categorie socială privilegiată, dispunea de funcţii, proprietăţi funciare impunătoare şi de un statut politic şi economic preferenţial. Din rândurile ei domnul ţării alegea şi numea pe dregătorii mari sau mici care puteau purta particula vel (mare), vtori sau treti (al doilea, al treilea) sau biv (fost). Funcţiile nu erau ereditare şi nici măcar pe viaţă. În perioada când domnii se schimbau des, soarta boierilor era nesigură ${ }^{17}$. Iar criteriile nobleţei în diferite perioade erau diverse: dregătoria, stăpânirea pământului sau neamul $^{18}$.

La începutul secolului al XIX-lea boierimea din Principatul Moldova prezenta o categorie socială superioară a societăţii, care deţinea principale funcţii în stat, cele mai mari proprietăţi de pământ şi putea, de cele mai multe ori, să se mândrească cu o spiţă genealogică veche. Datorită acestor caracteristici, boierimea şia creat o mentalitate proprie, manifestându-se atât prin modul de viaţă, vestimentaţie, locuinţe, petrecerea timpului liber etc., cât şi prin poziţiile în viaţ̧a publică, atitudinile şi reprezentările manifestate faţă de alte categorii sociale şi popoare, faţă de procesele şi evenimentele istorice care se întâmplau în ţară şi peste hotare.

Totodată, fără a realiza o analiză detaliată a acestor subiecte, constatăm că dvorenimea rusă era categoria socială privilegiată a societăţii ruse, care se caracteriza

\footnotetext{
${ }^{14}$ Cantemir 2001: 165.

${ }^{15}$ Moldova în epoca feudalismului 1998: 126.

${ }^{16}$ Moldova în epoca feudalismului 1998: 127.

${ }^{17}$ Diaconescu 1996: 1/237.

${ }^{18}$ Bacalov 2010: 47-48.
} 
printr-o dependenţă completă faţă de Putere, pentru că elementul definitoriu al nobleţei era nu proprietatea, ci serviciul, toţi cei ce „serveau” fiind socotiţi a o poseda $^{19}$. Statutul social, politic şi juridic al dvorenimii este reflectat în documentele administraţiei ţariste. Interesul major al administraţiei imperiale pentru dvorenime se explică prin faptul că aceasta era principalul susţinător al Imperiului, ea domina la Curte şi în cancelarii, la popotele regimentelor, în saloane şi săli de bal, la teatru şi în sălile de conferinţe, purtând hainele Imperiului şi vorbind limba acestuia ${ }^{20}$. De fapt, evoluţia dvorenimii ca categorie socială în Imperiul Rus a fost marcată de adoptarea a două documente de bază care reglementau drepturile, privilegiile şi obligaţiunile acestei stări sociale.

În primul rând este vorba de Tabelul rangurilor adoptat de țarul Petru I în $1722^{21}$, care plasa fiecare persoană în cele 14 ranguri militare, civile sau de la Curte. Conform acestuia, în determinarea poziţiei unei persoane în instituţiile statului o importanţă majoră o avea serviciul pe care îl îndeplinea faţă de Putere, şi nu originea sau vechimea, noblețea familiei. De fapt, Tabelul rangurilor instituit de Petru I a avut rolul de a înlocui statutul familial cu meritul apreciat prin educaţie, realizări şi experienţă, ca principal criteriu al promovării. Iar scopul Ţarului nu a fost de a submina elita existentă, ci de a o revitaliza prin pregătire, exemplu străin şi experienţă în muncă ${ }^{22}$.

Al doilea document care reglementează statutul dvorenimii ruse este Hrisovul despre drepturile, libertăţile şi privilegiile dvorenimii ${ }^{23}$, acordat acestei stări sociale la 21 aprilie 1785 de impărăteasa Ecaterina a II-a. Prin acest document noblețea devine o distincţie ereditară rezultată din calităţile şi virtuţile unor oameni remarcabili din trecut ${ }^{24}$, iar nobilimea rusă $\breve{2}^{25}$ a obţinut un şir de privilegii: drepturi personale (apărarea integrităţii corporale, dreptul la deţinerea blazoanelor proprii, serviciul de stat devine opţional); drepturi la proprietate (dreptul la deţinerea proprietăţii funciare şi a ţăranilor şerbi, scutirea de toate taxele şi impozitele, dreptul de a se ocupa cu

\footnotetext{
19 Tomuleţ 2014: 428-429.

${ }^{20}$ Hosking 2001: 117.

${ }^{21}$ ПСЗРИ, собр. І, т. VI, 1720-1722, № 3890. СПб., 1830, с. 486-493.

${ }^{22}$ Hosking 2001: 117-118.

${ }^{23}$ ПСЗРИ, собр. І, т. ХХІІ, 1785, № 16187, СПб., 1830, с. 344-358.

${ }^{24}$ Olteanu 2011: 63.

${ }^{25}$ Nobilimea se împărțea în două categorii: de viță (потомственные дворяне) şi personală (личные дворяне). Nobilimea de neam era alcătuită din şase categorii de bază, iar fiecărei categorii îi corespundea o parte specială din Cartea genealogică gubernială. Titlul de nobil personal nu putea fi transmis prin ereditate, nu dădea dreptul de a moșteni moşiile părinţilor împreună cu țăranii aflaţi pe aceste pământuri, de a se înscrie în societăţi nobiliare şi de a participa la adunările nobiliare. Începând cu 1832, copiii de nobili personali au primit drepturi onorabile cetățeneşti de moştenire. A se vedea detaliat: Tomuleţ 2014: 428-429.
} 
activitatea industrială şi comercială, dreptul la crearea unui organ al nobilimii Adunarea Nobilimii $)^{26}$ etc. Aceste documente vin să confirme dependenţa dvorenimii de putere, de împărat, criteriul principal al nobleţei în Imperiul Rus fiind serviciul exercitat cu credinţă faţă de administraţia ţaristă. Căci, aşa cum afirmă nobilul basarabean D.C. Moruzi, „baza aristocraţiei, pătura conducătoare a popoarelor, nu era, ca în alte ţări, naşterea, ci serviciile aduse Imperiului. Orice treaptă socială putea ajunge la nobleţe, servind pe Țar; iar nobilul, oricât de veche i-ar fi fost originea, de nu intra personal în serviciul Statului, pierdea titlurile şi privilegiile sale ${ }^{27}$.

Astfel dvorenimea rusă era una dintre categoriile sociale de bază existente în Imperiul Rus, având un statut special, ceea ce a favorizat crearea unei mentalităţi specifice.

Revenind la boierimea din Basarabia, trebuie să menţionăm că încă din secolul al XVI-lea întâlnim în istoria Moldovei pe marii boieri localizaţi între Prut şi Nistru. Dacă comparăm boierii din întreaga Moldovă cu cei dintre Prut şi Nistru, observăm că sunt aceiaşi boieri mari ai Curţii Domneşti de la Iaşi ${ }^{28}$. Cele mai multe familii din Basarabia se trag din strămoşi aşezaţi cândva între Prut şi Nistru sub lungile domnii ale lui Alexandru cel Bun şi Ştefan cel Mare. Îndeosebi boierii moldoveni erau răsplătiţi de domnii Moldovei cu întinse moşii de-a lungul Nistrului, pentru fidelitate, devotament şi iscusinţa în războaie şi pentru a fi acei străjeri împotriva vrăjmaşilor de la Răsărit ${ }^{29}$. În secolele XVII-XVIII găsim pe succesorii vechilor boieri: Râşcanu, Rusu, Cantacuzino, Balş, Sturdza, Catargi, Rosetti, Miclescu, Bogdan, Paladi, Ghica, Carp, Cazimir, Başota ${ }^{30}$ etc., care în mare parte deţineau aici proprietăţi funciare, pe care le gestionau locuind în partea dreaptă a Prutului.

După anexarea teritoriului dintre Prut şi Nistru, numărul neamurilor boiereşti care au trecut sub supuşenie rusă a fost redus. Viceguvernatorul Basarabiei - Wighel - susţine că după anexare în regiune au rămas vreo 7-8 familii care provin de la boieri din Moldova, şi anume: Sturdza, Balş, Rosseti, Donici, Krupenschi, Paladi, Catargi şi Râşcanu ${ }^{31}$. Nicolae Iorga prezintă însă alte nume boiereşti care pot fi întâlnite în Basarabia după anexare: „,ei doi Cantacuzini, Alexandru şi Gheorghe, pe vara lor Elenco, măritată cu Harting, pe Iamandieşti, pe un Şeptilici, un Andrieş, pe un Orâş, pe un Bantăş, pe un Hermeziu, pe mai mulţi Oatu etc" ${ }^{\prime 32}$. Despre prezenţa familiilor vechi în Basarabia relatează şi nobilul Pavel Cruşevan în romanul său Milioanele, în

\footnotetext{
${ }^{26}$ ПСЗРИ, собр. І, т. ХХІІ, 1785, № 16187, СПб., 1830, с. 344-358.

${ }^{27}$ Moruzi 1905: 4.

${ }^{28}$ Bezviconi 1943: 4.

${ }^{29}$ Iov 1932: 37.

${ }^{30}$ Iorga 1995: 231.

${ }^{31}$ Вигель 1892: 4.

${ }^{32}$ Iorga 1918: 6-7.
} 
care evidenţiază specificul nobilimii din Basarabia faţă de cea din alte regiuni. Căci, susţine autorul, nici într-un alt stat nu vom putea identifica urmaşi ai marilor dinastii, neamuri de viţă şi familii istorice mai mult ca în Basarabia: Cantacuzineştii - urmaşi direcţi ai împăraţilor bizantini; Paleologul, Comnena, Vataci - îşi aduc provenienţa lor de la Imperiul latin; Ghica, Sturdza, Moruzi, Radovani - fii şi nepoţii domnilor/gospodarilor moldoveni şi valahi ${ }^{33}$. Discrepanţele dintre aceste menţiuni, adică dintre cea promovată de istoriografia rusă modernă şi contemporană, potrivit căreia pe teritoriul dintre Prut şi Nistru nu au existat nobili şi cea susţinută de reprezentanţii istoriografiei româneşti care atestă prezenţa pe teritoriul dintre Prut şi Nistru a unor familii vechi, moldoveneşti, se explică prin faptul că administraţia ţaristă tindea să dovedească că pe teritoriul anexat la 1812 nu a existat o aşa categorie socială ca nobilimea, acesta fiind un spaţiu slab populat şi nedezvoltat.

Astfel, începând cu anul 1812 nobilimea din Basarabia s-a dovedit a fi favorizată de două sisteme social-economice şi politice care îi acordau diverse drepturi: statutul pe care îl deţinea conform tradiţiei locale, privilegiile acordate de domnul Constantin Mavrocordat şi statutul deţinut de către dvorenimea rusă, care în mod obligatoriu a revenit şi nobilimii basarabene. Dualitatea acestor două sisteme poate fi constatată analizând Regulamentul organizării administrative a regiunii Basarabia din 29 aprilie 1818. Conform Regulamentului, categoria socială privilegiată a boierilor din Basarabia a fost suprimată şi egalată în drepturi cu dvorenimea din guberniile interne ruse şi integrată în ea $^{34}$. Nobililor din Basarabia li se acordau aceleaşi drepturi şi privilegii de care se bucura nobilimea rusă şi, concomitent, i se păstrau toate drepturile, privilegiile şi rangurile deţinute până la anexare, adică specifice categoriei sociale a boierilor ${ }^{35}$. Totuşi, pentru ca boierii din Basarabia să se poată identifica cu titlul de nobil al Imperiului Rus, ei trebuiau să-şi confirme nobleţea.

Politica de confirmare a nobleţei a fost primită cu suspiciune de reprezentanţii nobilimii basarabene şi criticată de reprezentanţii administraţiei ţariste. Viceguvernatorul Basarabiei, Wighel, analizând statutul deţinut de boierimea moldovenească se întreba cum poate fi egalat un boier din Basarabia cu un dvorean ${ }^{36}$. Problema evocată de Wighel constă în faptul că, deşi în Moldova boierimea este stratificată ca şi în Imperiul Rus, coraportul dintre aceste stratificări nu era unul echivalent ${ }^{37}$. De exemplu, deţinătorii titlului de vel Logofăt sau Vistiernic, care

\footnotetext{
${ }^{33}$ Ижболдина 2012: 92.

34 Устав 1818: 16.

35 Устав 1818: 16.

${ }^{36}$ Вигель 1892: 31.

${ }^{37}$ Despre stratificarea nobilimii existentă în Principatele Române a se vedea detaliat: Arbore 1899: 734-735.
} 
aparţineau primei trepte în Moldova, la ruşi au fost egalaţi cu rangul de funcţionar de clasa a IV-a ${ }^{38}$. În pofida acestor discrepanţe, boierii moldoveni au fost încadraţi în sistemul rusesc al elitelor, aşa cum prevedea politica imperială. Căci stabilitatea în imperiu a fost menţinută inclusiv prin cooptarea elitelor locale şi integrarea lor în nobilimea şi birocraţia rusă. Această cooptare a avut rolul de a crea un imperiu multinaţional în principiu, precum şi acela de a distanţa şi mai mult elitele de masa largă a tuturor grupurilor etnice ${ }^{39}$.

Totodată, pentru a putea beneficia în continuare de privilegiile şi drepturile specifice acestei categorii sociale, boierimea din Basarabia a fost pusă în situaţia de a-şi confirma şi reconfirma pe parcursul secolului al XIX-lea nobleţea. Şi iarăşi constatăm un proces dual: pe de o parte, administraţia ţaristă acorda avantaje nobilimii din Basarabia, iar pe de altă parte prin examinarea documentelor depuse avea posibilitatea de a verifica persoanele cărora li se confirma nobleţea. Pentru început, administraţia ţaristă a încercat să alcătuiască o listă a nobililor din Basarabia. O primă încercare de a aduna nobilii din regiune şi de a întocmi o listă a acestora a fost întreprinsă la 22 iunie 1814, când la Chişinău a avut loc o adunare generală a boierilor cu scopul de a-şi exprima sentimentele de supuşenie Împăratului, contribuind totodată, printr-un dar de 150 de cai, la înzestrarea armatei ruse ${ }^{40}$. La adunarea (prezidată de Mitropolit) au participat aproximativ 48 de boieri, printre care spătarul I. Başotă, banul T. Başotă, paharnicul T. Stamati, comisul Şt. Râşcan, stolnicul M. Donici, căminarul Z. Ralli, fraţii Russo, generalul Catargi, paharnicul N. Doni, stolnicul M. Râşcan, medelnicerul L. Rosseti, fraţii Catargi, T. Crupenschi şi mulţi alţii ${ }^{41}$.

Abia începând cu anul 1816 administraţia imperială începe să organizeze clasa nobilimii basarabene. Tot din anul 1816 şi-au probat activitatea diferite comisii ${ }^{42}$ care aveau ca scop elaborarea tabelelor de „nobili”. Una dintre primele comisii, după cum afirmă Al. Crupenschi, a fost creată la cererea lui Svinin, sosit în Basarabia în 1815. În componenţa comisiei au intrat Ioan Sturdza, Alexandru Ghica, Ilie Catargi şi Ioan Pruncul în calitate de secretar. Ulterior Ilie Catargi refuză să participe la activitatea acestei comisii, invocând drept motiv starea de sănătate. La cererea membrilor comisiei acesta a fost înlocuit cu Petru Catargi ${ }^{43}$. Rezultatele activităţii comisiei nu sunt cunoscute. Istoricul Dinu Poştarencu susţine că, după toate

\footnotetext{
${ }^{38}$ Вигель 1892: 32.

${ }^{39}$ Hosking 2001: 40.

${ }^{40}$ Bezviconi 1939: 28. A se vedea detaliat: ANRM, F. 88, inv. 1, d. 4.

${ }^{41}$ Bezviconi 1996: 32.

${ }^{42}$ Comisia pentru examinarea dovezilor prezentate de nobilii din Basarabia în vederea acordării titlului de nobil: a se vedea detaliat: Tomuleţ 2014: 196-198; Poştarencu 2013, 64-74.

${ }^{43}$ Крупенский 1912: 10-11.
} 
probabilităţile, ar fi fost vorba despre examinarea de către Comitetul Provizoriu al Basarabiei a documentelor depuse de reprezentanţii categoriilor privilegiate. Conform ordinului dat de rezidentul plenipotenţiar al Basarabiei A.N. Bahmetev, toate categoriile sociale privilegiate trebuiau să prezinte până la 1 ianuarie 1817 documentele ce atestau starea lor socială, pentru a fi examinate de Comitetul Provizoriu ${ }^{44}$. Dar nici această încercare nu s-a soldat cu alcătuirea unei liste a nobililor din regiune. Întocmirea listei boierilor din Basarabia a devenit o necesitate odată cu adoptarea Regulamentului privind administrarea Basarabiei din 1818, conform căruia nobilimea a căpătat dreptul de a-şi crea propriul organ - Adunarea Deputaţilor Nobilimii $^{45}$. Respectiv, pentru organizarea alegerilor nobiliare era nevoie de o listă a nobililor. Din ordinul lui A. Bahmetev, după cum susţine F. Wighel în memoriile sale, a fost creată o comisie numeroasă care trebuia să cerceteze actele de noblețe prezentate de boieri. Comisia a existat doar 24 de ore şi deoarece dispunea de un ordin secret de a nu fi prea exigentă în procesul de cercetare a actelor de nobleţe, aceasta a confirmat titlul nobiliar numai pentru vreo 260 de familii $^{46}$. Conform altor date, publicate de Ioan Halippa în 1907, în această listă au fost înscrişi 145 de nobili pământeni ${ }^{47}$. Ulterior, A.N. Bahmetev, într-o comunicare oficială, referindu-se la procedeul de alcătuire a respectivei liste, susţine că deputaţii aleşi de către nobili trebuiau să alcătuiască o listă ,,în baza informaţiilor de care ei dispun, până se va da o nouă dispoziţie în acest sens" ${ }^{\prime 8}$. Anume din acest motiv rezidentul plenipotenţiar cere crearea unei comisii care urma să cerceteze noblețea boierilor. Ca rezultat, în 1821 împăratul Alexandru I aprobă Regulamentul cu privire la confirmarea calităţii de nobil conform rangurilor şi privilegiilor moldoveneşti, de care urma să se conducă comisia ce avea să fie instituită. Comisia a fost prezidată de către Guvernatorul Plenipotenţiar al Regiunii Basarabiei, locotenent-generalul Inzov; aceasta avea în componenţă mareşalul regional al nobilimii şi 12 dintre cele mai nobile persoane cunoscute în regiune. Această comisie a recunoscut rangul de nobleţe pentru 189 de familii, număr care în procesul de redactare a Cărţii Genealogice a neamurilor nobile din Basarabia $^{49}$ a fost redus în anul 1824 la 102 familii.

Astfel, odată cu instituirea comisiei, reprezentanţilor clasei nobiliare din Basarabia le-a fost prezentată lista actelor în baza cărora urma să le fie confirmat titlul de nobil ${ }^{50}$. La baza confirmării erau puse două documente. În baza Hrisovului lui

\footnotetext{
${ }^{44}$ Poștarencu 2013: 66.

45 Устав 1818: 24.

${ }^{46}$ Вигель 1892: 13.

${ }^{47}$ Poştarencu 2013: 69.

${ }^{48}$ Poştarencu 2013: 71.

${ }^{49}$ A se vedea detaliat: ANRM, F. 88, inv. 2, d. 290; Elita 2014: 27-66.

${ }^{50}$ Actele în baza cărora se confirma noblețea a se vedea detaliat: Bezviconi 1940: 12-18.
} 
Constantin Mavrocordat din 1734 erau recunoscuţi ca nobili toţi acei care au primit rangul moldovenesc de la vel Logofăt până la treti Logofăt $t^{51}$. Al doilea document care în viziunea noastră era mult mai important decât primul - este Hrisovul despre drepturile, libertătile şi privilegiile dvorenimii, acordat la 21 aprilie 1785, de impărăteasa Ecaterina a II-a, făcându-se în special referire la articolul 92, în care erau enumerate documentele ce făceau dovada incontestabilă a nobleţei ${ }^{52}$.

Astfel, practic începând cu anul 1821 şi pe parcursul secolului al XIX-leaînceputul secolului al XX-lea, reprezentanţii nobilimii basarabene au fost nevoiţi săşi confirme şi reconfirme în permanenţă noblețea. Acest proces a fost mult mai dificil pentru reprezentanţii vechii boierimi, pentru că administraţia ţaristă susţinea în special nobilimea noua, alogenă, care prezenta dovezi în baza Hrisovului Împărătesei Ecaterina a II-a şi nu a documentelor moldoveneşti. Fapt pe care îl vom argumenta prin studierea procesului de confirmare a nobleţei unor familii din Basarabia. De fapt, fiecare nobil care este inclus în Cartea Genealogică a neamurilor nobile din Basarabia are un dosar depozitat în Fondul Adunării Deputaţilor Nobilimii ${ }^{53}$. Neavând ca scop studierea în totalitate a acestor dosare ${ }^{54}$, vom analiza doar cele mai reprezentative, pentru a scoate în evidenţă direcţiile prioritare ale politicii imperiale ruse promovate, pe parcursul anilor, în ce priveşte confirmarea nobleței, după 1821, pe teritoriul dintre Prut şi Nistru.

\footnotetext{
${ }^{51}$ Lista rangurilor moldoveneşti, care acordau dreptul la demnitate de nobilime, de la vel Logofăt până la treti Logofăt: vel Logăfăt, vel Vornic, Vistiernic, Hatman, Postelnic, Cămăraş, Aga, Ban, Comis, Căminar, Paharnic, Serdar, Stolnic, Armaş, Medelnice, Clucer, Sluger, Pitar, Jitnicer, Şătrar, vtori Logofăt, vtori Postelnic, treti Logăfăt. A se vedea detaliat: Bezviconi 1940: 17-18.

${ }^{52}$ Conform articolului 92, printre documentele de confirmare a nobleţei se numărau: 1 . Diplomele pentru demnitate de noblețe acordate de administraţia imperială; 2. Blazoanele acordade de Împărat; 3. Diplomele pentru rangurile prin care se conferă noblețea; 4 . Actele confirmătoare că persoana a fost decorată cu un Ordin Cavaleresc Rusesc; 5. Dovezi prin diplome acordate sau de laudă; 6 . Ordinele de împroprietărire cu pământ sau sate; 7. Actele care confirmă primirea moşiilor pentru serviciul nobilimii; 8. Ordinele sau diplomele despre acordarea moşiilor; 9. Ordinele sau diplomele pentru satele sau moşiile conferite, chiar dacă acestea ar fi ieşit din stăpânirea neamului. 10. Ordinele şi hrisoavele date unui nobil pentru ambasadă, solie sau altă trimitere; 11. Dovezi că strămoşii au îndeplinit un serviciu corespunzător unui rang de nobil; 12. Dovezi că tatăl şi bunicul au dus un mod de viaţă, au avut un serviciu corespunzător statutului de nobil, fapt confirmat printrun certificat semnat de 12 nobili, despre a căror nobleţe nu exista nicio îndoială; 13. Actele de cumpărare, de ipotecă şi testamentele privitoare la averea nobililor; 13. Dovezi că tatăl şi bunicul au stăpânit sate etc. A se vedea detaliat: ПСЗРИ, собр. I, т. XXII, 1785, № 16187, СПб., 1830, c. 354-358.

${ }^{53}$ ANRM, F. 88, inv. 2, d. 304, 308, 311, 317, 318, 323, 330, 343, 352, 355, 358, 368, 386, 387, 395, $399,421,425,427$ etc.

${ }^{54}$ Despre procesul de confirmare a nobleței în Basarabia a se vedea: Poștarencu 2010: 25-36; Poştarencu 2013: 112-118; Tomuleţ, 2013: 104-141; Gherasim 2011: 84-88; Gherasim 2013: 119134; Gherasim 2014a: 231-249.
} 
De fapt, trebuie să menţionăm că, la început, procesul de confirmare a nobleţei era mult mai simplu, dat fiind faptul că administraţia ţaristă dorea să-şi creeze în noua regiune o bază socială în persoana boierilor basarabeni. Vom lua ca exemplu în acest sens reprezentanţii familiei de nobili Leonard ${ }^{55}$. Pavel Dimitrie Leonard şi copiilor acestuia nobleţea le-a fost confirmată de către comisia din 1821, fiind incluşi în Partea I a Cărţii Genealogice a neamurilor nobile. Ca argument de confirmare a nobleţei a servit certificatul eliberat de Divanul Principatului Moldova la 15 ianuarie 1814, prin care se confirma că Dumitru Leonard, tatăl şi bunelul actualilor petiţionari, este fiul vătafului Gheorghe Leonard şi nepotul şătrarului Leonard, care a venit în Moldova împreună cu domnul Gheorghe Ghica din Constantinopol. Şătrarul Leonard a fost căsătorit cu fiica boierului Bacsan, familie cu vechi rădăcini aristocratice, fapt ce atestă că neamul Leonarzilor, atât pe linie maternă, cât şi pe linie paternă, se trage din familii vechi aristocratice ${ }^{56}$. Veridicitatea documentului este confirmată în 1814 de reprezentanţii marilor boieri şi de Departamentul Afacerilor Externe din Principatul Moldovei ${ }^{57}$. Ulterior, la 2 noiembrie 1825, la Comisia pentru examinarea nobleţei a fost depusă o cerere de către reprezentanţii celeilalte ramuri a familiei Leonard - Costache (36 ani), Nicolae (27 ani) şi Vasile (22 ani), fiii lui Chiriac Leonard - prin care aceştia cer să le fie confirmat titlul nobiliar pentru că tatăl lor a deţinut rang boieresc în Ţara Moldovei ${ }^{58}$. Drept argument al nobleţei lor petiţionarii au prezentat mai multe documente. În primul rând, certificatul eliberat de Divanul Principatului Moldova la 15 octombrie 1815, confirmat de domnul Scarlat Alexandru Callimachi, care adeverea provenienţa nobiliară a serdarului Panaite Leonard, velstolnicului Costache Leonard şi a fratelui său Nicolae Leonard, fii pitarului Chiriac Leonard $^{59}$. La dosar au fost anexate alte două dispoziţii care confirmau deţinerea titlului boieresc de pitar $^{60}$. Concomitent, reprezentanţii Leonarzilor prezintă lista întocmită în 1806, pe timpul domniei voievodului Moruzi, care include persoanele scutite de impozite, drept motiv fiind invocată apartenenţa lor la categoriile privilegiate ale populaţiei. În această listă fiind indicat şi Chiriac Leonard, vel pitar ${ }^{61}$. Cererea şi documentele prezentate au fost studiate de către Adunarea Deputaţilor Nobilimii din Basarabia, care în baza actelor evidenţiate supra a hotărât confirmarea

\footnotetext{
55 Analizând documentele prezentate de reprezentaţii Leonarzilor pentru confirmarea nobleţei, putem constata că la începutul secolului al XIX-lea în Basarabia erau două ramificaţii ale familiei Leonard: cea descendentă de la Chiriac Dimitrie Leonard şi cea reprezentată de Pavel Dimitrie Leonard şi copiii acestuia.

${ }^{56}$ ANRM, F. 88, inv. 2, d. 608, f. 3.

${ }^{57}$ ANRM, F. 88, inv. 2, d. 608, f. 4.

${ }^{58}$ ANRM, F. 88, inv. 2, d. 323, f. 1.

${ }^{59}$ ANRM, F. 88, inv. 2, d. 323, f. 9, 9 verso, 120.

${ }^{60}$ Conţinutul dispoziţiilor a se vedea detaliat: ANRM, F. 88, inv. 2, d. 323, f. 40, f. 117, 119.

${ }^{61}$ ANRM, F. 88, inv. 2, d. 323, f. 40 verso.
} 
titlului nobiliar lui Costache, Nicolae şi Vasile Leonard şi includerea acestora în Partea I a Cărţii Genealogice a neamurilor nobiliare din Basarabia ${ }^{62}$.

Astfel, în anii '20-30 ai secolului al XIX-lea procesul de confirmare a nobleței avea un parcurs mai uşor, pentru că scopul administraţiei ţariste a fost de a crea o elită supranaţională, pentru a putea integra şi conduce diferitele popoare aflate în stăpânirea sa ${ }^{63}$.

Tendinţa de a-şi confirma nobleţea şi problemele întâlnite în acest sens sunt descrise de nobili şi în memoriile, lucrările lor artistice etc. De exemplu, Teodor Vârnav susţine în autobiografia sa că fiind în Moldova a trecut pe la Suceava, satul Petiea, pentru a aduna documentele confirmătoare a nobleţei: „mi-a dat adeverinţă (...) al cui fiu sunt, cine a fost părintele meu şi din ce neam se trag, cum şi alte documenturi şi gramoti de la domnii stăpânitori a Moldaviei, date în feliuri de vremi bunului meu jicniceriului Sandul Vârnav, moşului meu cluceriului Dimitrie Vârnav şi strămoşului meu stolnicul Teodor Vârnav" ${ }^{64}$. Toate documentele obţinute au fost întărite, după cum prevedea legislaţia despre confirmarea nobleței existentă în Basarabia, la isprăvnicia ţinutului Sucevei şi de Divanul Moldovei, ,căci împreună cu moşii paharnicul Vârnav şi Costache Chiruş (...) au mers pe la toţi aceia şi li-au arătat că sunt fiul lui Costachi Vârnav, (...) fără vreo deosebită vozrăjănie au încredinţat şi întărit pomenita mai sus adeverinţă, adăogând (...) că eu sunt curgător din acest Vârnăvesc neam de boieri’”65.

Totodată, trebuie să constatăm că politica promovată de administraţia ţaristă era una nesigură şi avea tendinţa de a crea o elită devotată Imperiului, ceea ce a permis încadrarea multor persoane fără noblețe în rândurile acestei categorii sociale. Ca rezultat, în scopul confirmării titlului nobiliar şi încadrării în rândurile nobilimii din Basarabia, o parte din „nobili” a falsificat documentele despre provenienţa sa, titlurile deţinute pentru a fi înscrisă în această categorie socială privilegiată. Mai ales că la începutul secolului al XIX-lea în Principatele Române titlurile de boierie nu mai erau date în dependenţă de dregătorie, ci puteau fi dobândite cu uşurinţă, inclusiv prin darea de mită ${ }^{66}$. Procesul de falsificare a actelor confirmatoare a nobleţei se răspândeşte şi mai mult în teritoriul dintre Prut şi Nistru după 1812. Astfel, o serie de reprezentanţi ai diferitelor categorii sociale pentru o „mulţumire” obţineau hrisoave de boierie de la voievodul mazilit Ioan Sturdza sau de la „meşterul” Holodnicov, care sub domnia lui Grigore Ghica falsifica actele de hărăzire a caftanului boieresc. Ca

\footnotetext{
${ }^{62}$ ANRM, F. 88, inv. 2, d. 323, f. 149, 149 verso.

${ }^{63}$ Hosking 2001: 39.

${ }^{64}$ Vârnav 2007: 67.

65 Vârnav 2007: 67-68.

${ }^{66}$ Despre procesul obţinerii titlului de boier la începutul secolului al XIX-lea a se vedea detaliat: Xenopol: 153-154.
} 
rezultat, în Basarabia de după 1812 apăreau mereu hrisoave noi şi „strămoşi”’ iluştri: „,copiii” erau mai în vârstă decât „părinţii”, iar gradele boierilor se hărăzeau „,boierilor în vârstă de 3-5 ani sau chiar de la naştere" ${ }^{67}$. Această situaţie este descrisă şi de viceguvernatorul Wighel, care susţine că, pe lângă cele 7 sau 8 familii de nobili care provin de la boieri moldoveni, sunt în jur de 80 de persoane care au realizat serviciul în războaiele ruso-turce, au primit diverse ranguri, cinuri, în baza cărora li-a fost confirmat titlul nobiliar ${ }^{68}$. Căci restul de boiernaşi - antreprenori şi spioni - şi-au alcătuit prin diverse mijloace averi fabuloase în timpul războiului cu turcii, apoi şi-au cerut de la ruşi (darnici în hărăzirea de grade moldoveneşti) diferite ranguri şi, în sfârşit, folosindu-se de Pacea din Bucureşti (termenul de 18 luni acordat pentru lichidarea avutului şi aşezarea pe o parte sau alta a Prutului) s-au stabilit definit în Basarabia, unde pentru sume neînsemnate şi-au dobândit latifundii de la boierii rămaşi în vechea Moldovă ${ }^{69}$. În această ordine de idei trebuie să constatăm că, pe lângă faptul că nobilii prezentau documente false, din anii '30-' 40 ai secolului al XIX-lea ei înşişi au început să elibereze documente false în numele Adunării Deputaţilor Nobilimii. Un astfel de caz a ajuns în atenţia Procurorului din judeţul Orhei în anul 1841. Conform informaţiei prezentate de acesta, Constantin Popovschi, locuitorul satului Chiperceni, nu numai că se identifica ilegal ca nobil, dar şi elibera adeverinţe false în numele Adunării Deputaţilor Nobilimii, prin care confirma nobleţea diferitelor persoane. Pentru o recompensă bănească, pseudo nobilul a eliberat între anii 18341838 şase adeverinţe false, după cum urmează: Gheorghe, Ştefan şi Andrei Galuşcov; Vasile şi Zaharia Bulat; Constantin şi Vasile Trelev; Vasile Stamati; Ion Antoci şi fiilor preotului din târguşorul Rezina - Petrache şi Maxim Onofrei ${ }^{70}$.

Astfel, persoane care până la 1812 nu beneficiau de drepturi şi privilegii specifice nobilimii s-au încadrat în noua nobilime din Basarabia. Mai ales că o aşa modalitate de încadrare era acceptată de administraţia țaristă, căci această ,nobilime nouă" era cea care susţinea politica imperială, pentru că îi acordase drepturi, privilegii şi, în general, un statut în societatea basarabeană. Iordache Varfolomeu, fruntaş vestit din Basarabia, este un exemplu elocvent în acest sens. Plin de vanitatea parvenitului îmbogăţit, el s-a înconjurat cu luxul pretenţios care trebuia să-i asigure, printr-o largă ospitalitate, prietenia şi sprijinul noii stăpâniri, lăsând uitării trecutul său prea dubios. De la ciubucciu pe scăricica butcii prinţului Moruzi, Varfolomeu ajunge să obţină la început gradul boieresc de clucer, apoi în schimbul unei mulţumiri lui Scarlat Callimachi obţine gradul boieresc de vel-serdar şi, temându-se de răzbunarea

\footnotetext{
${ }^{67}$ Bezviconi 1936: 2-3.

${ }^{68}$ Вигель 1892: 4.

${ }^{69}$ Bezviconi 1939: 19.

${ }^{70}$ ANRM, F. 924, d. 5, inv. 1, f. 1.1 verso, 2.
} 
turcească, se hotărăşte să se aşeze în părţile dintre Prut şi Nistru asigurându-şi averea sub pavăza rusească ${ }^{71}$.

Menţinerea sub control a nobilimii din Imperiu este dovedită şi prin faptul că aceasta trebuia să-şi confirme noblețea în repetate rânduri, iar deciziile luate de Adunarea Deputaţilor Nobilimii din Basarabia erau supuse unui proces de revizuire. Acest proces este unul din cele mai puternice contraargumente aduse istoriografiei ţariste, care susţinea că dacă până la anexare dreptul la noblețe nu se transmitea prin ereditate, atunci după 1818 boierii din Basarabia au obţinut acest drept. Cum rămâne atunci cu faptul că şi copiii, şi nepoţii, şi strănepoţii celor recunoscuţi la 1821 ca nobili au trebuit pe parcursul întregului secol al XIX-lea să-şi confirme şi reconfirme noblețea?

În anul 1834, în baza deciziei Senatului Guvernant din 30 mai, în Basarabia a fost instituită Comisia pentru revizuirea deciziilor Adunării Deputaţilor Nobilimii din Basarabia $^{72}$, alcătuită din doi membri din partea nobilimii şi unul din partea Guvernului, sub preşedinţia preşedintelui Judecătoriei de Conştiinţă din Basarabia C.I. Botezatu ${ }^{73}$. La 17 ianuarie 1839 Senatul Guvernant a emis o lege care confirma cooptarea în Comisia pentru revizuirea acţiunilor Adunării Deputaţilor Nobilimii din Basarabia şi în cea din Moghiliov a câte un traducător şi a câte un membru din partea Coroanei în guberniile Kiev, Podolia şi Volânia, precum şi aplicarea în Basarabia a legii din 18 decembrie $1836^{74}$, care prevedea regulile şi măsurile de urgentare a reviziei hotărârilor Adunării Deputaţilor Nobilimii ${ }^{75}$. Revizuirea hotărârilor luate de către Adunarea Deputaţilor Nobilimii din Basarabia a fost pusă în aplicare. De exemplu, numai în anul 1840 Comisia a revăzut actele de confirmare a nobleței familiilor Boţan, Orâş, Russo, Paleolog, Urbanovici, Solomon, Codreanu, Dimitriu, Machedon, Tomuleţ, Străjescu, Botezatu, Dracon, Varzari, Deleanu, Cazimir, Stroescu, Gusti, Hariton, Juravschi, Revencu, Stamati, Dângu, Roşca, Nestor, Afanasii Scordeli, Botezatu, Popovschi, Asnaş, Prohniţchi, Juravschi, Dodon, Bacinschi, Vârlaneşti, Baranovschi, Duca, Cassian, Lazo, Stamati, Bogdan, Meleghi, Casso $^{76}$ etc.

\footnotetext{
${ }^{71}$ Bezviconi 1947: 67.

72 Despre activitatea Comisiei pentru revizuirea deciziilor Adunării Deputaţilor Nobilimii din Basarabia a se vedea detaliat: Морозан 2012: 161-168.

73 Крупенский 1912, 20. Despre activitatea Comisiei pentru revizuirea deciziilor Adunărilor Deputaţilor Nobilimii din Basarabia a se vedea detaliat: Tomuleţ 2014: 199.

${ }^{74}$ Despre includerea în Comisia de revizuire a activităţii Adunării Deputaţilor Nobilimii a câte un membru de la Coroană şi a câte un traducător în guberniile Kiev, Podolia şi Volânia a se vedea detaliat: ПСЗРИ, собр. II, т. ХІІ, 1837, № 9912, СПб., 1838, с. 68-69.

75 ПСЗРИ, собр. II, т. ХІV, 1839, № 11940, СПб., 1840, с. 65.

${ }^{76}$ ANRM, F. 88, inv. 1, d. 997, partea I şi a II-a; ANRM, F. 88, inv. 1, d. 998, partea I şi a II-a.
} 
Rezultatele activităţii Comisiei confirmă că multe persoane cărora Adunarea Deputaţilor Nobilimii le-a recunoscut titlul de nobil au fost excluse din Cartea Genealogică a Neamurilor nobiliare din Basarabia, iar aceasta din cauza interpretării eronate de către membrii acestui organ a dreptului persoanelor respective la noblețe sau din cauza caracterului dubios al documentelor prezentate la 1821 pentru obţinerea titlului de nobil, fie din cauza neprezentării la timp a actelor necesare ${ }^{77}$. De exemplu, în raportul prezentat de către Comisia de revizuire a deciziilor Adunării Deputaţilor Nobilimii din Basarabia din 12 iunie 1840, sub nr. 83 se constată că pentru Panainte Dioghenidi, care în 1826 a fost recunoscut de Adunarea Deputaţilor Nobilimii ca nobil, s documentele prezentate nu confirmă trecerea în serviciul Statului Rus ${ }^{78}$.

Totuşi, din considerentul că în Basarabia ar fi existat mulţi nobili care şi-au confirmat noblețea prezentând acte false sau în baza vechilor documente moldoveneşti, la 29 ianuarie 1845 administraţia ţaristă a adoptat o nouă lege care se referea la confirmarea Cărţii Genealogice a neamurilor nobile din Basarabia. Prin această lege erau declarate valabile toate hotărârile despre confirmarea nobleței aprobate de Departamentul de Heraldică până se realiza o revizie a documentelor. Excepţie făceau 42 de familii de nobili din Basarabia, care erau înscrise în Cartea Genealogică dar nu prezentaseră la Departamentul de Heraldică documentele în baza cărora membrii lor au fost recunoscuţi ca nobili, fie prezentaseră drept argument pentru confirmare numai faptul că sunt înscrişi în Cartea Vistieriei din 1806 a Principatului Moldova. Conform aceleiaşi legi, acestor nobili li s-a acordat un termen de 2 ani pentru a prezenta documentele necesare. Totodată, legea confirma că locuitorilor Basarabiei li se adevereşte noblețea în baza Hrisovului de Stat din 1734, precum şi a documentelor emise de domnitorii Principatului Moldova ori de Divan, a hotărârilor judecătoreşti, a documentelor ce confirmă dreptul de proprietate asupra moşiilor şi asupra ţăranilor scutelnici de pe ele pe care persoana îl avea până la anexarea Basarabiei la Imperiul Rus, cu menţiunea că aceste documente vor fi valabile numai dacă va fi indicat rangul deţinut de proprietar ori dacă există date despre provenienţa nobiliară a neamului. Pentru confirmarea nobleţei se cerea şi prezentarea certificatului de naştere. În cazul în care nobilii nu dispuneau de acest act, se accepta şi prezentarea unor certificate veridice de la Divan. Totuşi, pentru cei născuţi după anexarea provinciei se insista asupra prezentării certificatelor de naştere. Pornind de la aceste prevederi, Adunarea Deputaţilor Nobilimii urma să înceapă revizuirea dosarelor de nobleţe confirmate atât de Comisia din 1821, cât şi de Adunarea Deputaţilor Nobilimii în perioada anilor $1821-1845^{79}$. Această lege a dus la revizuirea

\footnotetext{
77 Tomuleţ 2014: 199.

${ }^{78}$ ANRM, F. 88, inv.2, d.365, f. 20, 20 verso.

${ }^{79}$ ПСЗРИ, собр. II, т. ХХ, 1845, № 18678, СПб., 1846, с. 150-151.
} 
titlului de nobil (noblețe) tuturor nobililor incluşi în Cartea Genealogică a neamurilor nobile din Basarabia, care pentru unii reprezentanți s-a soldat cu necesitatea de a prezenta noi documente doveditoare a nobleței, alţii în general fiind lipsiţi de titlul nobiliar. În acest context vom aduce doar un singur exemplu, revenind la familia Leonarzilor. În conformitate cu noua lege din 29 ianuarie 1845, examinând dosarul familiei Leonard Departamentul de Heraldică a hotărât că documentele prezentate nu sunt suficiente pentru confirmarea titlului nobiliar. Din acest considerent a refuzat să confirme hotărârea Adunării Nobilimii Deputaţilor din Basarabia care recunoscuse nobleţea reprezentanţilor familiei Leonard încă în 1826. Dosarul a fost întors în 1848 Adunării Nobilimii Deputaţilor din Basarabia $^{80}$. Ca argument al deciziei Departamentului de Heraldică despre nerecunoaşterea nobleţei neamului Leonard a fost adus faptul că, pe lângă certificatul prezentat de Divanul Principatului Moldova din 15 octombrie 1814 care confirma rangurile boiereşti deţinute de reprezentanţii familiei Leonard şi provenienţa nobiliară a acestora, în conformitate cu legea din 1845 mai era nevoie şi de alte documente doveditoare ale nobleţei ${ }^{81}$. Din aceste considerente, la 23 decembrie 1862 Vasile Leonard a depus o nouă cerere Adunării Nobilimii Deputaţilor din Basarabia prin care aduce la cunoştinţă că, deşi el a fost recunoscut ca nobil al regiunii Basarabia, fiii săi Chiriac şi Nicolae nu deţineau acest titlul, considerent din care roagă ca urmaşii săi să fie recunoscuţi ca nobili ai regiunii Basarabia, în care scop prezintă documentele necesare ${ }^{82}$. Unul dintre documente este hotărârea Adunării Deputaţilor Nobilimii din Basarabia din 1 aprilie 1826 prin care stolnicul Costache, funcţionar de clasa a XIV-a, Nicolae şi Vasile, fiii pitarului Chiriac Leonard sunt introduşi în Partea I a Cărţii Genealogice a neamurilor nobile din Basarabia ${ }^{83}$. A fost prezentat şi formularul de serviciu, din care rezultă că pe parcursul serviciului Vasile Leonard a dat dovadă de devotament şi supuşenie țării, fiind decorat pentru aceasta cu ordinul Sfânta Ana de gradul $\mathrm{IV}^{84}$. La dosar erau anexate şi certificatele de naştere ale fiilor săi, eliberate la 2 noiembrie 1850 de către Consistoriul Duhovnicesc din Chişinău. Conform acestor certificate, constatăm că la 1 decembrie 1837 în familia proprietarului Vasile Leonard şi a soţiei sale Elena s-a născut fiul Nicolae ${ }^{85}$, iar la 4 noiembrie 1838 fiul Chiriac ${ }^{86}$. Cererea lui Vasile Leonard şi documentele prezentate pentru confirmarea nobleţei au fost examinate de Adunarea Deputaţilor Nobilimii din Basarabia la 12 noiembrie 1863. În urma analizei

\footnotetext{
${ }^{80}$ ANRM, F. 88, inv. 2, d. 323, f. 17.

${ }^{81}$ ANRM, F. 88, inv. 2, d. 323, f. 18, 18 verso.

${ }^{82}$ ANRM, F. 88, inv. 2, d. 323, f. 34, 34 verso, 101, 101 verso.

${ }^{83}$ ANRM, F. 88, inv. 2, d. 323, f. 40 verso.

${ }^{84}$ ANRM, F. 88, inv. 2, d. 323, f. 35.

${ }^{85}$ ANRM, F. 88, inv. 2, d. 323, f. 35 verso.

${ }^{86}$ ANRM, F. 88, inv. 2, d. 323, f. 36-36 verso.
} 
documentelor menţionate, conform deciziei Adunării s-a stabilit că deoarece lui Costache, Nicolae şi Vasile Leonard le-a fost recunoscut titlul de nobil şi ei au fost incluşi în Cartea Genealogică a neamurilor nobile din Basarabia, atunci şi fiilor Vasile, Chiril şi Nicolae să le fie confirmată noblețea, fiind incluşi în Partea a II-a a Cărţii ${ }^{87}$. Însă Departamentul de Heraldică, examinând la 21 februarie 1864 raportul Adunării Deputaţilor Nobilimii din Basarabia din 12 noiembrie 1863, a refuzat să confirme titlul de nobil pentru Nicolae şi Chiriac Leonard, invocând drept motiv faptul că în dosarul prezentat sunt documente care confirmă că Vasile Leonard provine din rândul nobililor greci, dar că nu este prezentat certificatul care să confirme că acesta şi fiii săi au trecut în serviciul şi supuşenia Rusiei ${ }^{88}$. Deşi la 15 martie 1867 Vasile Leonard este informat că trebuie să prezinte documentul care să certifice faptul că el şi fiii săi au trecut în serviciul Rusiei (în caz de neprezentare cererea lor despre confirmarea nobleţei fiind respinsă ${ }^{89}$ ), acesta refuză motivând că faptul rezultă implicit din ordinul de demisie emis pe numele lui şi din formularul de serviciu anexat la $\operatorname{dosar}^{90}$. Un alt reprezentat al familiei Leonard care a manifestat dorinţa să-şi confirme noblețea a fost Nicolae Chiriac Leonard. Acesta a depus o cererea pe numele Adunării Deputaţilor Nobilimii din Basarabia la 18 noiembrie 1863, prin care cerea să-i fie confirmat titlul de nobil ${ }^{11}$. Drept argument Nicolae Leonard prezintă formularul de serviciu, din care reiese că pe parcursul anilor a ocupat diverse funcţii în administraţia imperială, manifestând supuşenie şi devotament, obţinând diferite titluri. La fel, pentru a confirma că într-adevăr aparţine familiei de nobili Leonard, Nicolae prezintă certificatul de naştere eliberat la 12 august 1854 de către Consistoriul Duhovnicesc din Chişinău, care adeverea că la 26 aprilie 1843 în familia proprietarului Nicolae şi a soţiei sale Maria s-a născut fiul Chiriac ${ }^{92}$. În scopul confirmării nobleţei sale petiţionarul a prezentat şi certificatul emis de către mareşalul județean al nobilimii din judeţul Soroca, în care se atesta că „Chiriac Leonard este într-adevăr fiul lui Nicolae Leonard, care a fost recunoscut ca nobil al regiunii Basarabia, şi că Chiriac duce un mod de viaţă decent, însă nu este înscris în rândul nobililor"93. Examinând la 10 mai 1871 aceste documente, Departamentul de Heraldică a refuzat însă să-i confirme titlul de nobil lui Chiriac Nicolae Leonard. Motivul invocat era că toate documentele prezentate din Principatul Moldova pentru confirmarea nobleței nu erau autentificate de Consulatul Imperiului Rus de la Iaşi sau

\footnotetext{
${ }^{87}$ ANRM, F. 88, inv. 2, d. 323, f. 37, 37 verso, 38, 38 verso, 39, 39 verso.

${ }^{88}$ ANRM, F. 88, inv. 2, d. 323, f. 44, 44 verso.

${ }^{89}$ ANRM, F. 88, inv. 2, d. 323, f. 61, 61 verso, 62, 62 verso.

${ }^{90}$ ANRM, F. 88, inv. 2, d. 323, f. 64.

${ }^{91}$ ANRM, F. 88, inv. 2, d. 323, f. 67, 67 verso.

${ }^{92}$ ANRM, F. 88, inv. 2, d. 323, f. 71, 71 verso.

${ }^{93}$ ANRM, F. 88, inv. 2, d. 323, f. 72.
} 
de Ministerul Afacerilor Externe ${ }^{94}$. În situaţia creată, Adunarea Deputaţilor Nobilimii a intervenit la Consulatul Rus de la Iaşi cu rugămintea ca acesta să confirme documentele eliberate de autorităţile din Principatul Moldova ce vizează provenienţa nobiliară a reprezentanţilor familiei Leonard. Răspunsul de la Consulatul Rus din Iaşi a fost emis la 17 iulie 1871, prin care Adunarea Deputaţilor Nobilimii din Basarabia era informată că documentele prezentate de Nicolae Chiriac Leonard au semnături neclare şi nu pot fi descifrate, de aceea ele nu pot fi autentificate. În acelaşi rând, dat fiind că aceste documente sunt administrative şi nu au caracter de acte civile sau judecătoreşti, nu pot fi identificate nici copiile lor în arhivele statului Moldova. Reprezentanţii Consulatului recomandă ca Nicolae Leonard să depună cerere pentru a-i fi eliberate noi acte, după care acestea vor fi autentificate ${ }^{95}$.

Constatăm că procesul de reconfirmare a nobleței după adoptarea legii din 1845 era mai complicat, în special pentru familiile vechi boiereşti pentru care însăşi prezentarea documentelor doveditoare era un proces anevoios. De multe ori el se dovedea a fi imposibil, pentru că în Principatul Moldova în timpul numeroaselor războaie foarte multe acte au fost distruse. Totodată, susţinem ideea că procesul de reconfirmare a nobleței decurgea mai greu pentru că începând cu anii '50-'60 ai secolului al XIX-lea apare o grupare a nobilimii basarabene care se implică într-o mişcare naţională pasivă, realizând acţiuni de promovare a limbii române ${ }^{96}$, cerând păstrarea legislaţiei autohtone ${ }^{97}$, deschiderea tipografiei şi editarea ziarelor în limba română ${ }^{98}$ etc., mişcare din care, de fapt, făceau parte şi fraţii Leonard.

O altă caracteristică a politicii de confirmare a titlurilor nobiliare în Basarabia este că administraţia ţaristă aloca o atenţie deosebită încadrării alogenilor în rândul nobilimii. Politica imperială faţă de noile teritorii şi popoare de la periferii a fost pusă în discuţie şi de cărturarul şi diplomatul Alexandru Sturdza, fiul primului guvernator al Basarabiei, într-o carte finalizată la 1853 (Notions sur la Russie/ Menţiuni despre Rusia). „Ne pare rău - menţiona Alexandru Sturdza, - că în zilele noastre Rusia a ajuns la momentul critic (...) a centraliza, a rusifica, a şterge din ce în ce mai mult toate nuanţele locale, acesta este astăzi scopul principal ce preocupă puterea" ${ }^{\prime 9}$. În aceeaşi lucrare Alexandru Sturdza atrăgea atenţia asupra amplitudinii măsurilor de colonizare şi schimbare a compoziţiei sociale şi demografice în ţara sa de baştină: „Ruşii din interiorul Imperiului şi o mulţime de străini de toate naţiile curg puhoi şi

\footnotetext{
${ }^{94}$ ANRM, F. 88, inv. 2, d. 323, f. 88, 88 verso.

${ }^{95}$ ANRM, F. 88, inv. 2, d. 323, f. 94, 94 verso.

${ }^{96}$ Poştarencu 2012: 81-89.

97 Tomuleţ 2003: 278-286.

${ }^{98}$ Danilov 2011: 27-41, 75-112.

${ }^{99}$ Popa 2012: 92.
} 
fără încetare spre Basarabia"100. Faptul că procesul descris de Alexandru Sturdza a fost pus în aplicare şi la nivelul nobilimii este dovedit de multitudinea de dosare prezente şi depozitate în Fondul Adunării Deputaţilor Nobilimii din Basarabia al Arhivei Naţionale a Republicii Moldova, care se referă la reprezentanţii funcţionarilor ruşi, ai şleahtei poloneze şi ai altor alogeni ${ }^{101}$ care au prezentat documente doveditoare de confirmare a nobleţei: Petraşevski, Borşevski, Brodescu, Soltovski, Celinski, Berezovski, Afanasi, Cerneşevski, Prohniţki, Mihnevici, Eitner, von Metlercamf etc. $^{102}$

Un exemplu elocvent în acest sens ar fi confirmarea titlului de nobil de către reprezentanţii şleahtei poloneze. La început acest proces a decurs destul de anevoios. Faptul că procesul confirmării decurgea lent este reflectat în procesele-verbale ale şedinţelor Adunării Deputaţilor Nobilimii din Basarabia. De exemplu, la 18 aprilie 1825 Adunarea Deputaţilor Nobilimii din Basarabia, prezidată de mareşalul regional al nobilimii Ion Constantin Başotă şi în prezenţa deputaţilor nobilul Ion Capallo, serdarul Teodor Măcărescu, serdarul Pavel Măcărescu, clucerul Anton Burda, nobilul Iordache Feodosiu, a pus în discuţie plângerea şleahtei poloneze din Chişinău. Din cauza că nu le era recunoscută nobleţea, aceştia erau nevoiţi să achite impozite, însă ei au venit în Basarabia cu ştirea administraţiei imperiale, fiind în căutarea unui refugiu asigurat. De aceea, s-a hotărât că reprezentanţii şleahtei trebuie să prezinte certificate eliberate de acelaşi organ - Adunarea Nobilimii - însă din alte gubernii ale Imperiului Rus, prin care să se adeverească că ei sau strămoşii lor într-adevăr au fost confirmaţi în titlul nobiliar ${ }^{103}$. O altă problemă consta în faptul că documentele prezentate de şleahta poloneză erau scrise în limba poloneză. La 4 decembrie 1825 Adunarea Deputaţilor Nobilimii din Basarabia, prezidată de mareşalul regional al nobilimii Ion Başotă, a studiat adresarea Serviciului Economic de Stat. Acesta informează că în scopul realizării inventarierii documentelor şleahtei poloneze a depus trei cereri - din 1 iulie 1825, din 13 august 1825 şi din 3 septembrie 1825, prin care cere Adunării Nobilimii să-i trimită un traducător, fiindcă documentele sunt scrise în limba poloneză, iar organul nobilimii nu dispune de aşa persoană ${ }^{104}$. Problema a rămas însă nerezolvată. Ulterior, la 20 decembrie 1826 Adunarea Deputaţilor Nobilimii din Basarabia, prezidată de acelaşi Ion Başotă şi în prezenţa deputaţilor Ion Capallo, Constantin Razu şi Iordache Fedosiu (aceşti doi din urmă

\footnotetext{
${ }^{100}$ Popa 2012: 92.

101 Procesul de confirmare a alogenilor în rândul nobilimii din Basarabia a se vedea detaliat: Bacalov 2013, 139-145; Bacalov 2015 : 156-210; Gherasim 2014b: 12-14; Gherasim 2015: 110116.

102 ANRM, F. 88, inv. 1, d. 74, 127, 136, 140, 150, 179, 307; inv. 2, d. 372, 375 etc.

${ }^{103}$ ANRM, F. 88, inv. 1, d. 167, f. 27, 27 verso, 28, 28 verso, 29, 29 verso.

${ }^{104}$ ANRM, F. 88, inv. 1, d. 167, f. 71, 71 verso.
} 
nobili), a pus din nou în discuţie întrebarea referitoare la şleahta poloneză. Problema era că în ultimii ani fuseseră depuse foarte multe dosare cu referire la confirmarea nobleţei diferitelor reprezentanţi ai nobilimii alogene. Însă documentele din multe dosare erau eliberate cu foarte mult timp în urmă, în unele cazuri nefiind indicate privilegiile acordate nobililor prin Hrisovul din 1785 emis de Ecaterina a II-a. În baza celor analizate, Adunarea Deputaţilor Nobilimii din Basarabia a hotărât să fie întocmită lista acestor persoane care să fie prezentată Adunării Nobilimii din Podolia, iar aceasta să confirme dacă persoanele respective deţin cu adevărat titlurile indicate şi dacă au fost confirmate în rândul nobilimii din gubernia Podolia ${ }^{105}$. Astfel, numărul mare al reprezentanţilor şleahtei poloneze din Imperiul Rus, precum şi neclaritatea privind drepturile şi obligaţiile deţinute de aceştia, dar şi faptul că până la recunoaşterea nobleţei şleahta trebuia să facă serviciul militar şi să achite impozite pentru proprietăţile funciare deţinute, a atras atenţia administraţiei imperiale şi, ca rezultat, au fost aprobate un şir de legi care reglementau încadrarea străinilor în rândul nobilimii ruse. Conform legii din 1831, odată cu confirmarea titlului nobiliar reprezentanţilor şleahtei de către Departamentul Heraldic, acestora le erau recunoscute toate drepturile şi privilegiile pe care le deţinea şi dvorenimea rusă, iar în toate documentele (acte publice sau judecătoreşti) aceştia urmau să fie identificaţi cu numele de nobili şi nu de şleahtă. Reprezentanţii şleahtei cărora nu le-a fost recunoscută nobleţea erau împărţ̧iţi în două categorii - şleahta rurală şi şleahta orăşenească. Pentru a nu se confunda aceste două categorii, reprezentanţii şleahtei care n-au fost confirmaţi în rangul nobiliar şi locuiau la sate erau numiţi odnodvorţi, iar cei de la oraş - cetăţeni ${ }^{106}$, fapt confirmat prin legea din 11 noiembrie 1832 Despre împărţirea foştilor şleahtici în 3 categorii. Conform celor două legi, şleahta de pe teritoriul Imperiului Rus era împărţită în 3 categorii. Prima categorie era formată din nobili confirmaţi de Adunarea Deputaţilor Nobilimii sau neconfirmaţi, dar care deţin proprietăţi funciare populate şi ţărani fără de pământ. Aceştia beneficiază de privilegii specifice dvorenimii: nu achită niciun impozit şi nu sunt supuşi militari. A doua categorie este alcătuită din nobili confirmaţi doar de Adunarea Deputaţilor Nobilimii, dar care nu deţin proprietăţi imobiliare. Aceştia erau eliberaţi de orice obligaţie până la studierea dosarelor de către Departamentul Heraldic. În ultima categorie erau încadraţi reprezentanţii şleahtei cărora care nu le-a fost confirmată nobleţea şi nu deţineau proprietăţi imobiliare. Aceştia urmează să achite impozite şi să îndeplinească serviciul militar ${ }^{107}$.

\footnotetext{
${ }^{105}$ ANRM, F. 88, inv. 1, d. 210, f. 130, 130 verso.

106 ПСЗРЙ, собр. II т. VI, 1831, № 4869, СПб., 1832, с. 134-135.

${ }^{107}$ ПСЗРИ, собр. II, т. VII, 1832, № 5746, СПб., 1833, с. 836-837.
} 
Adoptarea acestor legi ${ }^{108}$ a avut un impact direct şi pentru nobilimea din Basarabia, astfel încât numărul şleahtei care şi-a confirmat nobleţea a crescut pe parcursul anilor. De exemplu, în 1837, Dimitriu, mareşalul regional al nobilimii, a înaintat în Consiliul Regional al Basarabiei o listă de 57 de familii de aristocraţi polonezi, cerând recunoaşterea drepturilor lor nobiliare. Dintre acestea au fost recunoscute şi incluse în Cartea Genealogică a neamurilor nobile din Basarabia următoarele familii: Urbanovici, Delimorkov, Oseţki, Gurski, Lazo, Nedzelinski, Coliski, Pragniţki şi altele ${ }^{109}$. Celorlalte familii le-au fost recunoscute dreptul şi privilegiile de care beneficiau nobilii ruşi. Dintre aceste familii putem menţiona: Tolmacevski, Iliniţki, Bacinski, Cerneavski, Popovski, Leviţki, Zinkevici, Bercovi, Radulov, Petraşevski, Juravski ${ }^{110}$ etc.

Reprezentanţilor şleahtei le era recunoscută foarte repede nobleţea. Analizând dosarele depuse de şleahta poloneză, observăm că reprezentanţilor acesteia li se confirma titlul nobiliar în urma prezentării unor certificate care adevereau că Adunarea Deputaţilor Nobilimii din Podolia deja recunoscuse apartenenţa lor nobiliară. Spre exemplu, Vasile Prohniţki (51 ani), locuitor al ţinutului Bender, a înaintat Adunării Deputaţilor Nobilimii din Basarabia o cerere prin care roagă ca el, soţia sa Ermina (30 ani) şi feciorii (Iacob de 19 ani, Ioan de 18 ani şi Tudor de 8 ani) să fie confirmaţi în rang nobiliar, fiind incluşi în Cartea Genealogică a neamurilor nobile din Basarabia. Drept argument principal pentru confirmarea nobleței acesta a prezentat traducerea raportului Adunării Deputaţilor Nobilimii din Podolia cu privire la confirmarea nobleţei sale şi a fratelui său, Anton Prohniţ̧ki ${ }^{111}$. Conform Raportului emis la 11 decembrie 1802, lui Anton şi Vasile, fiii lui Petru Prohniţki, le-a fost confirmat titlul nobiliar, ei fiind incluşi în Partea I a Cărţii Genealogice a neamurilor nobile din gubernia Podolia. Ca dovadă a apartenenţei lor la rangul nobiliar aceştia au prezentat certificatele de naştere eliberate la 8 decembrie 1802 de Consistoriul Duhovnicesc al ţinutului Baltic, care confirmau că Petru şi Ecaterina Prohniţki au doi feciori: Vasile născut la 20 aprilie 1777 şi Anton născut la 10 iulie $1779^{112}$. În baza acestor documente reprezentanţilor familiei Prohniţki le-a fost recunoscut titlul nobiliar, fiind incluşi în rândurile nobilimii basarabene.

\footnotetext{
108 Alte legi referitoare la încadrarea şleahtei poloneze în rândurile nobilimii basarabene şi ruseşti a se vedea detaliat: ANRM, F. 88, inv. 1, d. 553, passim; ПСЗРИ, собр. II, т. VII, 1832, № 7198, СПб., 1833 с. 461; ПСЗРИ, собр. II, т. ХІІІ, часть 2, 1838, № 11387, СПб., 1839, с. 5-7; ПСЗРИ, собр. II, т. XV, часть 1, 1840, № 13048, СПб., 1841, с..4-6 etc.

${ }^{109}$ Накко 1879: 170.

110 Накко 1879: 170.

${ }^{111}$ ANRM, F. 88, inv.1, d. 307, f. 9-9 verso.

112 ANRM, F. 88, inv.1, d. 307, f. 6-6 verso, 7-7 verso.
} 
Aceeaşi situaţie o identificăm şi în cazul familiei de nobili polonezi Celinski. Conform documentelor existente, la 9 noiembrie 1827, în adresa Adunării Deputaţilor Nobilimii din Basarabia a fost depusă o cerere semnată de Grigorii, fiul lui Erasmus, Ion şi Pantelimon, fiii lui Iosif Celinski, locuitori ai oraşului Chişinău. Drept argument aceştia au prezentat extrasul din hotărârea Adunării Deputaţilor Nobilimii din Podolia, eliberat la 2 decembrie 1819 , şi adeverinţa din 5 februarie 1820, eliberată de acelaşi organ, ambele servind ca dovadă a faptului că ei sunt membri ai familiei Celinski şi sunt de provenienţă nobilă. Ca urmare, lor le-a fost recunoscut titlul nobiliar şi au fost incluşi în Partea I a Cărţii Genealogice a neamurilor nobile din Basarabia ${ }^{113}$. Drept argument a servit faptul că, potrivit extrasului prezentat, se confirmă că Adunarea Deputaţilor Nobilimii din Podolia, prezidată de mareşalul regional al nobilimii Mihail Kuţkevici, a examinat cererea nobililor Iosif şi Grigorii Celinski, locuitori ai guberniei Kiev, şi a recunoscut nobleţea lor. Adunarea Nobilimii îşi argumentează decizia în baza următoarelor documente: actul care se referea la pierderile suferite de locuitorii localităţii Markuşov în timpul refugiului regelui Carol XII (,, небытности короля”), unde este menţionat ca membru al administraţiei nobilul Anton Celinski, străbunicul actualilor solicitanţi, certificatul de naştere al lui Grigorii (9 mai 1760) şi al lui Iosif (1768), precum şi o adresare a membrilor familiei Celinski către nobilul Malinovschi prin care primii pretind la o parte din proprietatea funciară a acestuia, fiind indicată provenienţa lor de la nobilul Anton Celinski. În baza acestor documente Adunarea Deputaţilor Nobilimii din Podolia a recunoscut nobleţea lui Iosif şi Grigorii Celinski ${ }^{114}$. În conformitate cu cererea şi documentele prezentate, Adunarea Deputaţilor Nobilimii i-a recunoscut pe Grigorii, fiul lui Erasmus, pe Ion şi Pantelimon, fiii lui Iosif Celinski, ca nobili din regiunea Basarabia.

Or, de cele mai multe ori reprezentanţii şleahtei poloneze, care au venit aici cu doar câteva ruble în buzunar, deţineau funcţii în poliţie sau, arendând proprietăţi funciare, cu timpul deveneau mari proprietari de terenuri. Astfel, se întâmpla că de cele mai dese ori cei care erau cu adevărat nobili, din lipsă de resurse financiare, nu puteau obţine documentele şi dovezile care ar confirma apartenenţa lor nobiliară, iar cei care aveau bani, deşi nu erau după provenienţă nobili, obţineau acest titlu ${ }^{115}$. Ca rezultat, pe parcursul secolului al XIX-lea, alături de boierii moldoveni autohtoni, în procesul de confirmare a titlurilor nobiliare desfăşurat de Comisia instituită în acest scop s-au încadrat şi reprezentanţi ai nobilimii alogene. Cercetând zeci de dosare ale nobilimii autohtone, comisia nu le recunoştea multora noblețea. În acelaşi timp, funcţionarii alogeni, care nu erau de neam nobiliar, erau trecuţi fără nicio piedică în

\footnotetext{
${ }^{113}$ ANRM, F. 88, inv. 1, d. 150, f. 13-13 verso.

${ }^{114}$ ANRM, F. 88, inv. 1, d. 150, f. 14-14 verso, 15-15 verso.

115 Накко 1879: 150.
} 
Cartea Genealogică a neamurilor nobile din Basarabia. Acest fapt denotă că guvernul rus nu era interesat în a li se confirma boierilor basarabeni titlul de nobil, temându-se de ei ca de o forţă politică; dimpotrivă, era interesat în dispersarea acestei categorii sociale ${ }^{116}$.

În procesul de confirmare a nobleței, în special a alogenilor, o importanţă deosebită o avea prezentarea formularului de serviciu, a diferitelor diplome şi decoraţii etc., acestea servind ca dovadă a serviciului şi credinţei manifestate faţă de Ţar şi de Imperiul Rus. Anume din acest considerent, dosarelor de arhivă prezentate de către alogeni chiar în primii ani de după anexare le sunt alăturate formularele de serviciu, care conţin informaţii despre vârsta, proprietăţile, statutul familial şi, cel mai important, despre cariera în administraţia civilă sau militară. Astfel, Bogdan Eitner prezintă pentru confirmarea nobleţei formularul de serviciu, patentele precum că deţine rangurile militar (sublocotenent) şi civil (funcţionar de clasa a VIII-a), precum şi decretul despre decorarea lui cu ordinul Sfântul Stanislav de gradul IV ${ }^{117}$. Aceeaşi situaţie atestăm şi în cazul lui Teodor Mihnevici, care pentru confirmarea nobleței prezintă formularul său de serviciu, diploma despre meritele lui deosebite faţă de statul rus timp de 15 ani, diploma care confirmă că este decorat cu ordinul Sfântul Stanislav de gradul 4. În baza acestor documente Bogdan Eitner şi copiii lui au fost recunoscuţi nobili şi introduşi în Partea a II-a a Cărţii Genealogice a neamurilor nobile din Basarabia ${ }^{118}$. Iar lui Teodor von Metlercamf, originar din oraşul Hamburg, trecut în serviciul Rusiei, i s-a confirmat nobleţea în Basarabia pentru că a participat la campaniile militare împotriva lui Napoleon Bonaparte şi la războiul ruso-turc din 1828-1829. Pentru meritele deosebite faţă de administraţia imperială rusă a fost decorat cu ordinul Sfânta Ana de gradul III (7 octombrie 1829) şi cu ordinul Sfântul Vladimir de gradul IV (4 iunie 1830) ${ }^{119}$.

Urmaşii nobilimii autohtone, în special începând cu anii '40-'50 ai secolului al XIX-lea, prezintă aceleaşi ,formulare de credinţă” pentru confirmarea nobleței. Nicolae Stamo, din funcţionar de clasa a X-a evoluează în funcţionar de clasa a VIIa, ocupând funcţiile de traducător în Adunarea Deputaţilor Nobilimii din Basarabia, de preşedinte al Judecătoriei Ţinutale din Hotin, de judecător de pace de onoare în judeţul Hotin ${ }^{120}$. Dumitru Crupenschi, de la simplu soldat în armata rusă a ajuns să deţină rangul de căpitan de cavalerie pe lângă Statul Major, ulterior fiind ales mareşal judeţean în județele Bender şi Akkerman ${ }^{121}$. Aceeaşi avansare în funcţii înregistrăm

\footnotetext{
116 Samoilenco 2008: 181.

${ }^{117}$ ANRM, F. 88, inv. 2, d. 373, f. 1-2, 3-5 verso, 7-7 verso, 9-9 verso, 11-11 verso.

118 ANRM, F. 88, inv. 2, d. 372, f. 1, 1 verso, 3-3 verso, 4, 5, 7-9 verso, 11-12.

${ }^{119}$ ANRM, F. 88, inv. 2, d. 375, f. 2, 10 verso, 11.

${ }^{120}$ ANRM, F. 88, inv. 1, d. 1907, f. 3-7.

${ }^{121}$ ANRM, F. 88, inv. 1, d. 1907, f. 17-24.
} 
şi la alţi reprezentanţi ai nobilimii basarabene autohtone, ca: Teodor Crupenschi ${ }^{122}$, Dumitru Russo ${ }^{123}$, Gheorghe Donică-Iordăchescu ${ }^{124}$, Egor Patrachi ${ }^{125}$, Dumitru Suruceanu ${ }^{126}$, Pavel Leonard ${ }^{127}$, Victor Lazo ${ }^{128}$, Ion Russo ${ }^{129}$, Dumitru Meleli ${ }^{130}$, Nestor Dânga ${ }^{131}$, Gheorghe Tomuleţ ${ }^{132}$, Gheorghe Donici ${ }^{133}$ etc.

Astfel începe un proces de asimilare sau, altfel spus, un război lent. Căci, menţionează nobilul basarabean Pavel Cruşevan, scriitor, „s-a început un război/o luptă lentă, fără vărsare de sânge, luptă neobservabilă şi insesizabilă, dar neîntreruptă zi de zi (...) Cuceritorii înaintau lent, pas cu pas, ei începeau cu nimic (...), dar treptat, la toate punctele îi băteau pe basarabeni, alungându-i din cuiburile sale, unde ei s-au născut, crescut, unde au trăit generaţie din generaţie, unde îşi alegeau şi aranjau fiecare colţişor, fiecare bucăţică de pământ (...) Unde nu te uiţi, practic în fiecare loc victorios s-a instalat străinul-cuceritorul" "134.

Totodată, trebuie să constatăm că complicarea procesului de confirmare a nobleţei s-a răsfrânt şi asupra reprezentanţilor şleahtei poloneze, în special după revolta din $1863^{135}$. Ca argument prezentăm cazul familiei de nobili Cernilev/Cernelevski cărora, deşi organele competente din Basarabia le-a recunoscut noblețea la 25 februarie 1831 în baza hotărârii Adunării Deputaţilor Nobilimii din Podolia din 18 decembrie $1802^{136}$, ulterior cererea de reconfirmare a titlului de nobil le-a fost respinsă. Astfel, fiii lui Nicolai Cernilev, Ion, Pahomii şi Ştefan, întâmpină greutăţi în ce priveşte confirmarea nobleţei. Deşi ca argument la cererea lor aceştia prezintă documentele care adeveresc deţinerea tilului de nobil în Basarabia, certificatele de naştere eliberate de Consistoriul Duhovnicesc din Chişinău cu nr. 7107, 5792, 5791, 5793 care demonstrează că sunt fiii legitimi ai lui Nicolae Cernilev, cererea lor este totuşi respinsă ${ }^{137}$, drept motiv servind răspunsul primit de la Adunarea Deputaţilor Nobilimii din Podolia referitor la dosarul de confirmare a nobleței acestei

${ }^{122}$ ANRM, F. 88, inv. 1, d. 1907, f. 26-31.

${ }^{123}$ ANRM, F. 88, inv. 1, d. 1907, f. 32-33.

${ }^{124}$ ANRM, F. 88, inv. 1, d. 1910, f. 14-19.

${ }^{125}$ ANRM, F. 88, inv. 1, d. 1910, f. 21-29.

${ }^{126}$ ANRM, F. 88, inv. 1, d. 1910, f. 104-113.

${ }^{127}$ ANRM, F. 88, inv. 1, d. 1902, f. 46-54.

${ }^{128}$ ANRM, F. 88, inv. 1, d. 1902, f. 75-79.

${ }^{129}$ ANRM, F. 88, inv. 1, d. 1902, f. 148-149.

${ }^{130}$ ANRM, F. 88, inv. 1, d. 1978, f. 76,

${ }^{131}$ ANRM, F. 88, inv. 1, d. 1967, f. 98-100.

${ }^{132}$ ANRM, F. 88, inv. 1, d. 1967, f. 126-127.

${ }^{133}$ ANRM, F. 88, inv. 1, d. 1967, f. 148-151.

${ }^{134}$ Крушеван 2012: 116.

${ }^{135}$ Gumenâi 2012: 251-255.

${ }^{136}$ ANRM, F. 88, inv.1, d. 150, f. 32-32 verso.

${ }^{137}$ ANRM, F. 88, inv.1, d. 150, f. 59-59 verso. 
familiei. Conform acestuia, la 18 decembrie 1802 membrii familiei Cernilev/Cernelevski au fost recunoscuţi ca nobili de Adunarea Deputaţilor Nobilimii din Podolia, fiind urmaşii lui Andronache Cerneli, boier din Ţara Moldovei care deținea rangul de paharnic, ceea ce-i dădea dreptul la noblețe ereditară. Însă, în baza deciziei din 11 martie $1841 \mathrm{cu}$ privire la persoanele cărora le-a fost recunoscut titlul nobiliar dar care n-au fost incluse în Cartea Genealogică a neamurilor nobile din Podolia, printre cei incluşi în categoria persoanelor care achită impozite se numără şi membrii familiei Cernilev. De asemenea, Adunarea Deputaţilor Nobilimii din Podolia informează că dosarul cu toate documentele în baza cărora le-a fost confirmat, la 1802, titlul nobiliar a fost pierdut ${ }^{138}$. În situaţia creată, Ion, Ştefan, Pahomii şi Isidor Cernilev/Cernelevski, din satul Gordineşti, târgul Lipceni, judeţul Orhei şi ultimul din oraşul Chişinău, informează la 19 aprilie 1873 Adunarea Deputaţilor Nobilimii din Basarabia despre faptul că cele două cereri (de la 25 februarie 1854 şi la de 10 februarie 1871) depuse pentru confirmarea nobleței au fost respinse, din care considerent roagă să fie incluşi în categoria odnodvorţilor ${ }^{139}$. Totodată, roagă să li se elibereze dosarul depus pentru a-1 prezenta Consiliului Regional, unde acesta urmează să fie analizat, după care va fi luată decizia cu privire la includerea lor în categoria odnodvorţilor $^{140}$. În acest scop anexează la dosar un certificat eliberat la 14 aprilie 1873 prin care reprezentanţii societăţii odnodvorţilor din târgul Lipceni, judeţul Orhei îşi dau acordul ca ei să fie acceptaţi în această categorie socială ${ }^{141}$.

Analizând aceste documente, putem concluziona că în Basarabia existau situaţii când reprezentanţilor şleahtei poloneze nu li se recunoştea nobleţea; respectiv, ei nu se bucurau de privilegiile şi drepturile specifice acestei categorii sociale, considerent din care erau nevoiţi să adere la alte categorii sociale mai puţin privilegiate. În cazul familiei Cernilev/Cernilevski aceştia cer să fie incluşi în categoria odnodvorţillor, o categorie socială la fel privilegiată din Basarabia, în care după 1847 au fost incluşi mazilii şi ruptaşii, scutită de prestaţii, care avea propria cârmuire sătească şi care în loc de impozitul pe familie (birul) plătea o dare numită dajdie, mai mică decât birul.

În concluzie putem constata că prin politica de confirmare a nobleței administraţia ţaristă a tins să controleze starea socială superioară a societăţii, să-şi creeze o bază socială care urma să susţină şi să promoveze politica imperială în teritoriul nou-anexat. Totodată, ţarismul tindea să cultive în cadrul nobilimii basarabene ideea că nobleţea lor şi, respectiv, beneficierea de toate drepturile şi privilegiile specifice acestei categorii sociale depinde de calitatea serviciului de

\footnotetext{
${ }^{138}$ ANRM, F. 88, inv.1, d. 150, f. 62-62 verso.

${ }^{139}$ Despre odnodvorţi a se vedea detaliat: Tomuleţ 2014: 415-418.

${ }^{140}$ ANRM, F. 88, inv.1, d. 150, f. 67-67 verso.

${ }^{141}$ ANRM, F. 88, inv.1, d. 150, f. 112-112 verso.
} 
credinţă şi supuşenie manifestate faţă de Imperiu şi Maiestatea Sa Împăratul. În acelaşi timp, administraţia ţaristă nu a ezitat să disperseze această categorie socială prin acceptarea alogenilor în rândurile nobilimi basarabene. Ca rezultat, importante funcţii administrative din regiune au fost ocupate de reprezentanţii nobilimii noi, fidele regimului ţarist. Astfel, odată cu infiltrarea alogenilor în rândurile nobilimii basarabene s-a produs schimbarea componenţei etnice, rusificarea şi deznaţionalizarea acestei categorii sociale. Aceste procese, în viziunea noastră, au suplimentat acel climat psihologic care a dus la metamorfozarea mentalităţii nobilimii basarabene, transformând-o (de multe ori în apartenenţă) într-o categorie socială credincioasă politicii ţariste. De fapt, această politică a dus la dedublarea personalităţii nobililor: o ipostază avea aceasta ca reprezentant al nobilimii ruse, adică în viaţa publică, şi cu totul altă ipostază avea în viaţa privată.

\section{BIBLIOGRAFIE}

Surse arhivistice

Arhiva Naţională a Republicii Moldova (ANRM), Fondurile F. 88; F. 924.

\section{Colecţii de documente}

Elita social-politică şi economică a Basarabiei sec. XIX-începutul sec. XX. Vol. I, Documente (2014). Coordonator Sergiu Bacalov. Chişinău: Bons Offices.

Moldova în epoca feudalismului. Vol. VIII, Documente moldoveneşti din secolul al XVIII-lea (1711-1750). Cărţi domneşti şi zapise. I Coordonator: Demir Dragnev. Chişinău, 1998.

Полное Собрания Законов Росийской Империи (ПСЗРИ) (1830а), собр. I, т. VI, 1720-1722, № 3890. Санкт-Петербург, 1830, сc. 486-493.

ПСЗРИ (1830b ), собр. I, т. XХІІ, 1785, № 16187, СПб., с. 344-358.

ПСЗРЙ (1832), собр. II т. VI, 1831, № 4869, СПб., с. 134-135.

ПСЗРИ (1833а), собр. II, т. VII, 1832, № 5746, СПб., с. 836-837.

ПСЗРИ (1833b), собр. II, т. VII, 1832, № 7198, СПб., с. 461;

ПСЗРИ (1838), собр. II, т. ХІІ, 1837, № 9912, СПб., с. 68-69.

ПСЗРИ (1839), собр. II, т. ХІІІ, часть 2, 1838, № 11387, СПб., с. 5-7;

ПСЗРИ (1841)собр. II, т. XV, часть 1, 1840, № 13048, СПб., , с. 4-6 etc.

ПСЗРИ (1840), собр. II, т. XIV, 1839, № 11940, СПб., с. 65.

ПСЗРИ (1846), собр. II, т. ХХ, 1845, № 18678, СПб., с. 150-151.

Устав образования Бессарабской области 1818 г. Кишинев, 1818.

\section{Surse bibliografice}

Arbore, Zamfir (1899). Basarabia în secolul al XIX-lea. Bucureşti: Institutul de Arte Grafice Carol GoBL. Furnisor al Curţii Regale. 
Bacalov, Sergiu (2010). Boierimea Ţării Moldovei la începutul epocii moderne (secolul al XVII-lea - inceputul secolului al XVIII-lea) (I). În: Revista de Istorie a Moldovei. Chişinău, 2010, nr. 1.

Bacalov, Sergiu (2013). Etnici ucraineni în mediul elitei basarabene în secolul al XIX-lea. Cazul lui Vladimir Djuminschi. În: Studii de arhondologie şi genealogie, vol. I. Chişinău, pp. 139-145.

Bacalov, Sergiu (2015). Nobilii basarabeni de origine franceză Ponset/Poncet stăpânii moşiei Leuntea din ţinutul Bender. În: Studii de arhondologie şi genealogie, vol. III. Chişinău, pp. 156-210.

Bezviconi, Gheorghe (1936). Din vremea lui Alexandru Sturdza (1791-1854). În: Din trecutul nostru (Chişinău), anul IV, nr. 36-39, pp. 1-81.

Bezviconi, Gheorghe (1939). Familia Crupenschi in Basarabia. În: Din trecutul nostru, Chişinău, anul VII, nr. 10.

Bezviconi, Gheorghe (1943). Vechea elită de dincolo de Prut. În: Profiluri de ieri şi de azi. Articole. Bucureşti.

Bezviconi, Gheorghe (1996). Semimileniul Chişinăului. Chişinău: Museum.

Bezviconi, Gheorghe (1940). Boierimea Moldovei dintre Prut şi Nistru (Actele Comisiei pentru cercetarea documentelor nobilimii din Basarabia la 1821). Vol. I. Bucureşti: Fundaţia Regele Carol I.

Bezviconi, Gheorghe, Calimachi, S. (1947). Puşkin în exil. Bucureşti: Presa.

Cantemir, Dimitrie (2001). Descrierea Moldovei. Chişinău: Litera.

Danilov, Maria (2011) Presa şi cenzura în Basarabia. Documentar, secolul al XIXlea - începutul secolului XX. Chişinău.

Diaconescu, Zoe (1996). Boieri şi mazili români în teritoriile înstrăinate (Bucovina şi Basarabia). În: Arhiva Genealogică (Iaşi) III (VIII), pp. 1/237-13/250.

Djuvara, Neagu (1995). Între Orient şi Occident. Ţările Române la începutul epocii moderne. Bucureşti: Humanitas.

Gherasim, Cristina (2011). Confirmarea titlurile nobiliare în Basarabia după anexarea la Imperiul Rus (cazul familie Donici). În: Materialele Conferinţei ştiinţifice internaţionale „Consolidarea şi dezvoltarea statului de drept în contextul integrării europene”. Vol. I. Secţia Istoria. Chişinău, 2011, pp. 8488.

Gherasim, Cristina (2013). Neamul de nobili Măcărescu. În: Studii de arhondologie şi genealogie. Vol. I. Chişinău, pp. 119-134.

Gherasim, Cristina (2014a). Familia de nobili Leonard. În: Studii de arhondologie şi genealogie. Vol. II. Chişinău, pp. 231-249.

Gherasim, Cristina (2014b). Încadrarea alogenilor în rândul nobilimii din Basarabia în secolul al XIX-lea. (Familia Metlercampf). În: Conferinţa ştiinţifică naţională cu participare internaţională, Integrare prin cercetare şi inovare, 10- 
11 noiembrie 2014. Rezumate ale comunicărilor. Ştiinţe umanistice. Chişinău, pp. 12-14.

Gherasim, Cristina (2015). Încadrarea şleahtei poloneze în rândurile nobilimii Basarabene pe parcursul secolului al XIX-lea (Cazul familiilor de nobili Celinski şi Cernilev/Cernelevschi). În: Studia Universitatis Moldavie. Revistă ştiinţifică a Universităţii de Stat din Moldova, Seria "Ştiinţe umanistice” (Chişinău), Anul IX, 2015, nr. 4 (84), pp. 110-116.

Giurescu, Constantin C. (1946). Istoria românilor. De la moartea lui Mihai Viteazul până la sfârşitul epocii fanariote (1601-1821). Vol. III, Partea II. Bucureşti: Fundaţia pentru literatură şi artă.

Gumenâi, Ion (2012). Nobilimea basarabeană, evenimentele poloneze din 1863 şi loialitatea faţă de Ţarul rus. În: Tratatul de Pace de la Bucureşti din 1812. 200 de ani de la anexarea Basarabiei de către Imperiul Rus. Materialele Conferinţei Internaţionale, Chişinău, 26-28 aprilie 2012. Chişinău: Pontos, pp. 251-255.

Hosking, Geoffrey (2001). Rusia-popor şi imperiu. 1552-1917. Iaşi: Polirom.

Iorga, Nicolae (1918). Continuitatea spiritului românesc în Basarabia. Iaşi: Tipografia ziarului „Neamul Românesc”.

Iorga, Nicolae (1995). Basarabia noastră. În: Neamul Românesc din Basarabia. Vol. I. Ediţie îngrijită de Iordan Daţcu. Bucureşti: Editura Fundaţiei Culturale Române.

Iov, Dumitru (1932). Boierii moldoveni de peste Prut. În: Viaţa Basarabiei, Chişinău, 1932.

Ижболдина, Ирина. «Живая старина» в произведениях русских литераторов Бессарабии кониа XIX-начала XX вв. Кишинев: Civitas.

Крупенский, Ал. (1912). Краткий очерк бессарабского дворянского собрания. СПб.

Крушеван, Павел (2012). Дойна. În: Ижболдина И. «Живая старина» в произведениях русских литераторов Бессарабии конца XIX - начала XX вв. Кишинев: Civitas, c. 115-117.

Mitrică, I.D., Temelie, Petrache (s.a.), Marele Nicolae Bălcescu despre boierii noştri. Craiova: TIP, „Viitorul”.

Морозан, Владимир (2012). Комисия по ревизии действий Бессарабского Дворянского Депутатского Собрания. În: Tyragetia, vol. VIII (XXIII), nr. 2, cc. 161-168.

Moruzi, Dumitru C. (1905). Basarabia şi viitorul ei. 1812-1905. Bucureşti: Tipografia ziarului Cronica.

Накко, А. (1879). Бессарабская область в историческом, экономическом и статистическом отношении (рукопись). Кишинев. (Manuscrisul se 
păstrează în fondul de manuscrise a bibliotecii Universităţii de Stat din Odesa).

Olteanu, Antoneta (2011). Rusia imperială. O istorie culturală a secolului al XIX-lea. Bucureşti: ALL.

Popa, Ioan C. (2012). Țărănimea şi biserica - piloni ai apărării identităţii româneşti in Basarabia. În: Limba Română. Revistă de ştiinţă şi cultură, Chişinău, Anul XXII, nr. 5-6 (203-204).

Poştarencu, Dinu (2010). Nobilii basarabeni Dicescu. În: Tyragetia. Istoria. Muzeologia. Seria nouă. Vol. IV (XIX), nr. 2, Chişinău, pp. 25-36.

Poştarencu, Dinu (2012). Eliminarea, în 1828, a limbii române din sistemul administrativ al Basarabiei. În: Limba Română. Revistă de ştiinţă şi cultură (Chişinău), anul XXII, nr. 5-6 (203-204). pp. 81-89.

Poştarencu, Dinu (2013). Introducerea instituţiei nobiliare în Basarabia. In: Nobilimea basarabeană în epoca reformelor din Imperiul Rus. În memoria lui Alexandru Matei Cotruţă. Chişinău, 2013, pp. 64-74.

Rosetti, Radu (1907). Pământul, sătenii şi stăpânii în Moldova. De la origini până la 1834. Tomul 1. Bucureşti: Ateliere grafice SOCEC \&Co, Societatea Anonimă.

Samoilenco, Valentina (2008). Boierimea din Basarabia în secolul al XIX-lea. Statut social şi juridic. In: Frontierele spaţiului românesc în context european. Oradea, pp. 178-191.

Tomuleț, Valentin (2003). Poziţia nobilimii basarabene şi a administraţiei de stat imperiale privind codificarea legislaţiei în Basarabia (În baza raportului secretarului de stat Urusov din 13 octombrie 1867). În: Analele ştiinţifice ale Universităţii de Stat din Moldova. Seria „Ştiinţe socioumanistice”, Volumul III. Chişinău: CE USM, pp. 278-286.

Tomuleț, Valentin (2013). Familia de nobili din Basarabia - Sandulache şi Tomuleţ. In: Nobilimea basarabeană în epoca reformelor din Imperiul Rus. În memoria lui Alexandru Matei Cotruţă. Chişinău, pp. 104-141.

Tomuleț, Valentin (2014). Basarabia în epoca modernă (1812-1918). Instituţii, termeni, regulamente. Chişinău: Lexon-Prim.

Vârnav, Teodor (2007). Istoria vieţii mele. Chişinău: Elan Poligraf SRL.

Вигель, Ф.Ф. (1892). Замечания на нынешнее состояние Бессарабии, писано в октябре 1823 года. Москва: Университетская типография.

Xenopol, A.D. (1988). Istoria românilor din Dacia Traiană. Ediţia a III-a. Vol. X: Istoria Țărilor Române de la Pacea de la Bucureşti până la răsturnarea fanarioţilor (1812-1821). Bucureşti: Editura „Cartea Românească”. 